\title{
Pelatihan Massage Akupressur pada Kelompok Bidan sebagai Asuhan Komplementer pada Ibu Hamil Trimester III
}

\author{
Ni Gusti Ayu Pramita Aswitami ${ }^{1 *}$, Ni Putu Mirah Yunita Udayani ${ }^{2,}$ I G.A. \\ Manik Karuniadi ${ }^{3}$, Luh Putu Widiastini ${ }^{4}$ \\ 1,2,3,4 STIKES Bina Usada Bali \\ *Email: tami_chant@yahoo.com
}

\begin{abstract}
Background: Pregnant women in third trimester $85 \%$ have complain with lower back pain. Management of back pain in pregnant women can be done by nonpharmacology, one of them with acupressure therapy. Acupressure therapy is one of complementary midwifery care services. The purpose of this activity is that midwives are able to provide complementary care in the form of acupressure therapy to improve health and reduce complaints of back pain in pregnant women. Methods: The acupressure therapy training activity was attended by 20 midwives who were held at STIKES Bina Usada Bali. This activity is carried out in 3 stages, namely the planning stage, the implementation phase and the evaluation phase. Evaluation is done by measuring knowledge using a questionnaire and acupressure practice skills using a checklist. Results: The results of community service activities indicate an increase in knowledge of midwives about acupressure therapy and an increase in the skills of midwives in conducting acupressure techniques. Conclution: It is recommended that community service providers provide training with a greater area coverage and midwives are expected to implement the results of this training to pregnant women especially those with back pain.
\end{abstract}

Keywords: acupressure, back pain, pregnancy

\section{PENDAHULUAN}

Indikator keberhasilan pembangunan di bidang kesehatan dapat dilihat dari angka kematian ibu (AKI) dan angka kematian bayi (AKB). Indonesia termasuk negara berkembang yang sampai saat ini masih berupaya dalam menurunkan AKI dan AKB dalam mencapai target keempat dan kelima MDG's 2015. Indonesia berada di posisi tertinggi di Asia Tenggara sebagai negara dengan catatan pelaporan AKI tertinggi dimana terjadi 228 kematian per 100.000 kelahiran hidup, yang selanjutnya meningkat menjadi 359 per 100.000 kelahiran hidup (Kemenkes, 2018). Komplikasi kehamilan, persalinan, dan nifas menjadi penyebab langsung kematian ibu, dimana sebanyak 32\% ibu hamil mengalami hipertensi kehamilan, 31\% mengalami komplikasi puerperium, 20\% mengalami perdarahan post partum, 4\% mengalami abortus, 3\% mengalami perdarahan antepartum, 2\% karena kelainan amnion, $1 \%$ disebabkan oleh partus lama, dan lain2 sebanyak $7 \%$.

Selain penyebab langsung, kematian ibu juga bisa terjadi karena penyebab tidak langsung. Penyebab tidak langsung yaitu penyakit diluar karena kahmilan dan persalinannya (Penelitian dan Pengembangan Kesehatan Kementerian Kesehatan RI, 2018). Dalam meningkatkan pelayanan bagi ibu dan bayi yang berkualitas hal ini menjadi tantangan yang sulit bagi bangsa Indonesia, apalagi ke depannya sudah dihadapkan pada target SDG's. Peningkatan dari segala aspek telah diupayakan dalam rangka menurunkan kematian ibu dan bayi, mulai dari aspek peningkatan akses pelayanan kesehatan terutama di dareah-daerah terpencil dan pelayanan kesehatan yang harus ditingkatkan agar menjadi pelayanan yang 
berkualitas, kuantitas dan kualitas tenaga kesehatan yang harus ditingkatkan terutama bidan, dan jaminan kesehatan.

Bidan memiliki peran yang sangat krusial terhadap peningkatan kualitas ibu dan anak salah satunya pada pelayanan ante natal care (Global Health Workforce Alliance, Kementerian Kesehatan RI, 2011). Bidan diharapkan dapat mengupgrade kompetensi dalam memberikan pelayanan atau asuhan secara komprehensif dan komplementer. Salah satu pelayanan komplementer yang dapat diberikan oleh bidan kepada ibu hamil adalah melakukan terapi akupresur. Terapi akupresure berguna untuk kesehatan ibu hamil.

Seiring dengan bertambahnya usia kehamilan, uterus akan membesar dan gravitasi akan berpusat ke arah depan, hal ini membuat ibu hamil saat berdiri harus benar-benar bisa memposisikan dirinya, karena selama kehamilan ibu lebih banyak bertumpu pada kekuatan otot, berat badan yang bertambah sifat relaksasi sendi, kelelahan serta postur sebelum hamil. Saat ibu hamil tidak bisa menyesuaikan postur tubuh dengan tepat maka akan terjadi peregangan yang maksimal dan menyebabkan kelelahan dan pegal di area punggung bagian bawah sehingga timbul rasa sakit atau nyeri pada punggung bagian bawah (Aswitami \& Mastiningsih, 2018). Nyeri merupakan rasa tidak menyenangkan yang dirasakan seseorang secara subjektif dimana rasa itu merupakan suatu pengalaman sensorik maupun emosional. Nyeri punggung bawah pada kehamilan dianggap menjadi penyebab terganggunya kenyamanan ibu dalam melewati kondisi hamil (Stewart, 2014). Negara seperti Amerika Serikat, Kanada, Iceland, Turki, Korean dan Israel, insiden nyeri pada ibu hamil yaitu sebanyak 50\%. Ibu hamil mengalami nyeri punggung bawah yang mengganggu aktifitas ibu sehari-hari, dan secara tidak langsung mempengaruhi kualitas hidup ibu hamil tersebut (Sneag \& Bendo, 2007). Di Indonesia sendiri, prevalensi nyeri punggung bawah di masa kehamilan baru diperoleh dari data yang didapat dari penelitian Suharto (2001) dilaporkan bahwa dari $180 \mathrm{ibu}$ hamil yang dijadikan subjek penelitian, $47 \%$ mengalami nyeri punggung bawah.

Banyak ibu hamil yang menganggap nyeri punggung bawah bukanlah suatu hal yang perlu di khawatirkan, namun sebenarnya apabila tidak ditangani dengan baik dan lebih awal, prognosis nyeri punggung bawah akan menjadi buruk. Biasanya ibu hamil dengan nyeri punggung bawah akan kesulitan saat beraktivitas, misalnya kesulitan untuk mengambil posisi dari duduk lalu berdiri, begitu pula sebaliknya, bahkan ibu akan mengalami kesulitan untuk turun dari tempat tidur. Jika hal tersebut berlangsung terus menerus dan tidak ditangani dengan baik, maka jangka panjangnya nyeri akan menyebar ke daerah panggul dan lumbar, hal ini akan menyebabkan ibu kesulitan untuk berjalan.

Berbagai teknik komplenter diantaranya: terapi pijat $(61,4 \%)$, relaksasi $(42,6 \%)$, yoga $(40,6 \%)$ dan akupresur $(44,6 \%)$ sudah diteliti dan dikembangkan untuk mengatasi nyeri punggung bawah pada ibu hamil (Wang eel., 2005). Akupresur merupakan bagian dari fisioterapi dimana teknik ini diberikan dengan pemijatan dan stimulasi yang difokuskan pada titik-titik tertentu pada tubuh, sehingga sakit dan nyeri yang dirasakan akan berkurang serta peredaran 
energi vital dan chi akan aktif kembali. Pengertian akupressure ini sangat sesuai dengan research yang dilakukan oleh peneliti Taiwan tentang terapi akupressure yang digunakan untuk mengobati nyeri punggung bawah dimana hasil penelitian tersebut menyatakan bahwa nyeri punggung bawah dapat diatasi dengan terapi akupresure dan manfaatnya terbukti efektif selama 6 bulan.

Nyeri punggung bawah selama ini dianggap sebagai hal yang wajar selama kehamilan, dan untuk mengurangi keluhannya biasanya ibu hamil cukup dengan istirahat saja, padahal keluhan ini dapat memberikan prognosis yang buruk. Kondisi ini memerlukan upaya, untuk meningkatkan kualitas kesehatan ibu hamil tersebut. Setelah mengindentifikasi permasalahan ini, maka dilakukan kegiatan pengabdian masyarakat dalam bentuk pelatihan terapi akupresur pada kelompok bidan, sehingga harapannya kelompok bidan ini akan memiliki kompetensi serta mampu memberikan pelayanan komplementer berupa terapi akupresur pada asuhan antenatalcare untuk mengurangi keluhan serta meningkatkan kualitas hidup ibu hamil.

\section{TINJAUAN PUSTAKA}

\subsection{Akupresur}

Akupresur merupakan terapi komplementer dengan prinsip healing touch yang lebih menunjukkan perilaku caring pada pasien sehingga dapat memberikan perasaan tenang, nyaman dan rileks. Ada juga yang menyatakan akupresur adalah seni penyembuhan kuno dengan menggunakan jari untuk menekan titik-titik penyembuhan secara bertahap yang merangsang kemampuan tubuh untuk penyembuhan secara alami (Noviyanti, 2016). Melalui terapi akupresur, tubuh akan melepaskan ketegangan otot, meningkatkan sirkulasi darah dan meningkatkan kekuatan hidup energi tubuh (qi) untuk membantu penyembuhan.

Terapi akupresur dapat digunakan untuk menghilangkan rasa sakit dan meringankan nyeri otot punggung (Noviyanti,2016). Akupresur memiliki manfaat sebagai berikut:

a. Pencegahan penyakit

Akupresur dipraktikkan secara teratur pada saat tertentu sesuai dengan aturan yang ada, yaitu sebelum sakit. Tujuannya untuk mencegah masuknya penyebab penyakit dan mempertahankan kondisi tubuh.

b. Penyembuhan penyakit

Akupresur dapat digunakan untuk proses penyembuhan keluhan sakit dan dilakukan dalam keadaan sakit.

c. Rehabilitasi

Akupresur digunakan untuk meningkatkan kondisi kesehatan sesudah sakit.

Menurut penelitian (Pravikasari,2014), terdapat ratusan titik akupresur pada permukaan tubuh. Titik ini adalah tempat terakumulasinya (berkumpulnya) energi vital. Semua titik- titik tersebut dapat digunakan sebagai titik diagnosis maupun titik terapi. Menurut fungsinya ada tiga jenis titik akupresur. Titik pertama yaitu titik tubuh atau titik umum. Titik ini adalah titik yang berada di sepanjang meridian. titik ini langsung berhubungan dengan organ dan daerah lintasan meridiannya. Titik 
kedua yaitu titik istimewa. Titik ini berada di luar lintasan meridian dan mempunyai fungsi khusus. Terakhir adalah titik nyeri. Titik nyeri adalah titik yang terdapat pada daerah keluhan jika di berikan tekanan selalu terasa nyeri dan fungsinya hanya simptomatis, penghilang rasa nyeri.

Cara menentukan lokasi titik pemijatan yang benar ada beberapa cara yang dapat dilakukan, antara lain menggunakan tanda anatomis tubuh, seperti benjolanbenjolan tulang,garis siku atau garis telapak tangan, putting susu, batas rambut, lipatan tangan dan sebagainya. Cara kedua yaitu pembagian sama rata, dimana suatu bagian tubuh tertentu dibagi sama rata untuk mendapat titik yang tepat serta menggunakan pedoman lebar jari. Dalam penekanan atau perangsangan akupresur ada beberapa hal yang harus diperhatikan, yaitu reaksi yang akan ditimbulkan, kondisi pasien dan jenis keluhan yang dialami pasien.

Arah pemijatan disesuaikan dengan sifat penyakit yang diderita oleh pasien. Sifat penyakit Yang, se, panas, luar maka pemijatan pada titik akupresur yang dilakukan adalah berlawanan dengan jarum jam sebanyak 60 putaran atau dengan istilah sedate. Sedangkan, sifat penyakit Yin, si, dingin, dalam maka pemijatan yang dilakukan adalah searah dengan jarum jam sebanyak 30 putaran. Dalam pemijatan, sebaiknya jangan terlalu keras dan membuat pasien kesakitan. Pemijatan yang benar harus dapat menciptakan sensasi rasa nyaman, pegal, panas, perih, kesemutan dan lain sebagainya. Apabila sensasi rasa dapat tercapai maka sirkulasi chi (energi) dan xue (darah) menjadi lancar, juga akan merangsang keluarnya hormon endorphin.

Akupresur menerapkan beberapa teknik pemijatan. Teknik pertama yaitu menekan. Penekanan dapat dilakukan dengan ibu jari, telunjuk, dan jari tengah yang disatukan dalam kepalan tangan. Penekanan dilakukan di daerah keluhan dengan tujuan untuk mendeteksi jenis keluhan meridian atau organ, selain untuk melancarkan aliran energi dan darah. Teknik kedua yaitu memutar. Memutar dilakukan didaerah pergelangan tangan atau kaki. Tujuan dari metode memutar adalah meregangkan dan merelaksasikan otot- otot yang mengalami ketegangan. Teknik ketiga adalah mengetuk. Mengetuk biasanya melibatkan gerakan mengetukngetuk titik- titik meridian organ. Biasanya dengan menggunakan jari tengah, atau ibu jari, jari telunjuk dan jari tengah yang disatukan dan dilakukan setiap 2-3 detik sekali selama beberapa menit. Teknik keempat yaitu menepuk. Menepuk digunakan untuk mendorong aliran energi dan darah. Caranya dengan menepuk telapak tangan yang terbuka sebanayak 5-10 kali pada berbagai meridian. Teknik yang terakhir adalah menarik. Menarik dilakukan untuk menarik jari-jari tangan atau kaki dengan cara diurut terlebih dahulu kemudian ditarik secara perlahan menggunakan jari jempol dan telunjuk dengan tenaga yang pelan dan tidak secara mendadak.

\subsection{Teknik Menangani Nyeri Punggung Bawah}

Titik utama yang dapat digunakan untuk berbagai macam penyebab nyeri punggung bawah yang dilakukan pemijatan berlawanan arah jarum jam (sedate) antara lain titik BL (blader) 23 (Shenshu), dua jari kiri dan kanan meridian GV, setinggi batas bawah lumbal kedua (Kemenkes, 2015). Titik GV 3 (gouvernor 
vessel) (Yaoyangguan), terletak diantara lumbal ketiga dan keempat. Titik GV 4 (gouvernor vessel) (Mingmen), terletak diantara lumbal kedua dan ketiga. Titik Ki 3 (taixi), terletak antara melleolus internus dengan tendon archiles (Pravikasari, 2014). Pada kasus nyeri punggung yang mengalami perubahan struktur tulang, terapi dilakukan 1 minggu sebanyak 3 kali pertemuan sampai keluhan benar-benar hilang. Sedangkan pada kasus nyeri punggung bawah ringan terapi dapat dilakukan selama 3 minggu, setiap minggunya akan dilakukan 2 kali pertemuan (Pravikasari, 2014).

\section{METODE}

Pada kegiatan pengabdian masyarakat ini, bahan yang dipersiapkan serta digunakan meliputi LCD, Laptop,mikrofon serta materi yang telah disusun oleh tim. Untuk kegiatan praktik, yang dipersiapkan adalah probandus, pakaian massage serta baby oil atau VCO. Metode kegiatan ini meliputi 3 tahap yaitu tahap penyampaian teori, tahap praktik dan tahap evaluasi. Tahap pertama dilakukan dalam bentuk ceramah dan tanya jawab mengenai teori dasar akupresur. Tahap kedua dilanjutkan dengan kegiatan demonstrasi atau praktik massage akupresur. Pada akhir kegiatan dilaksanakan evaluasi berupa kuesioner untuk mengetahui tingkat pengetahuan dan ketrampilan kelompok bidan setelah diberikan pelatihan akupresur. Berikut adalah tahapan pengabdian masyarakat:

\section{a. Tahap Perencanaan}

Pada tahap ini Ketua dan anggota tim pengabdian melakukan pendataan bidanbidan yang memiliki praktik klinik mandiri di daerah Badung dan Denpasar. Membuat serta menyebarkan surat undangan pelatihan ke bidan-bidan. Melakukan konfirmasi keikutsertaan dan diperoleh sejumlah 20 orang bidan yang mengikuti pelatihan. Menyusun materi dasar-dasar akupresur dan Standar Operating Procedure massage akupresur pada ibu hamil. Menyusun alat evaluasi berupa kuesioner dan daftar checklist massage akupresur. Mempersiapkan tempat untuk pelaksanaan kegiatan

\section{b. Tahap Pelaksanaan}

Tahap pelaksanaan dilakukan 2 kali pertemuan dalam seminggu pada tanggal 10 dan 11 Oktober tahun 2019 pukul 09.00 WITA - selesai.

\section{c. Tahap Evaluasi}

Tahapan ini dilakukan dengan mengadakan evaluasi untuk mengetahui tingkat pengetahuan dan praktik massage akupresur pada kelompok bidan.

\section{HASIL}

Berikut adalah hasil pelatihan yang diberikan kepada 20 orang bidan tentang terapi akupresur. Pelatihan ini mengevaluasi pengetahuan serta praktik terapi akupresur. Berikut adalah hasil pengetahuan teori dasar akupresur pre test dan post test : 


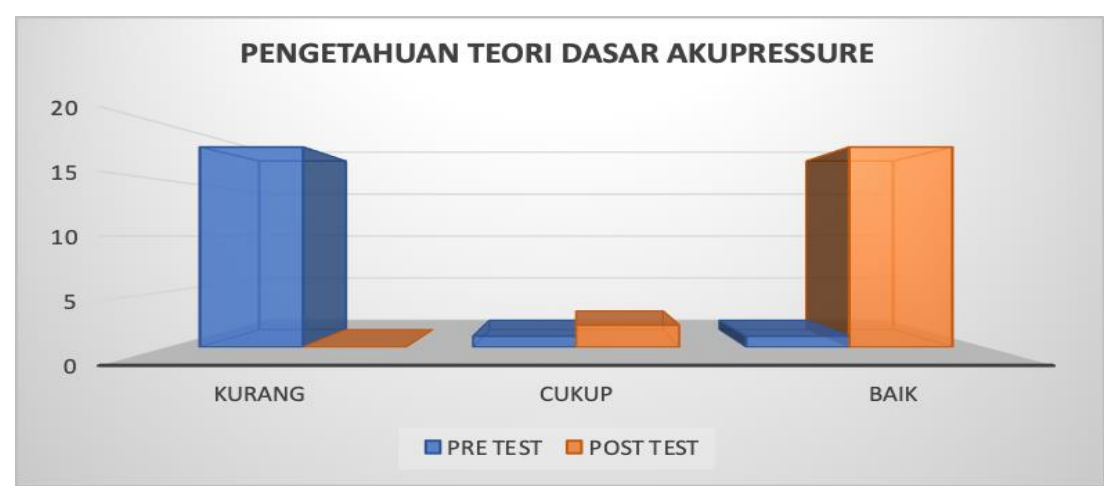

Gambar 1. Perhitungan Hasil Evaluai Pengetahuan

Perhitungan hasil evaluasi pengetahuan sebelum diberikan pelatihan akupresur sebanyak 18 orang $(90 \%)$ memiliki pengetahuan kurang, 1 orang $(0,5 \%)$ memiliki pengetahuan cukup dan 1 orang $(0,5 \%)$ memiliki pengetahuan baik. Setelah diberikan pelatihan akupresur sebanyak 18 orang $(90 \%)$ memiliki pengetahuan baik dan 2 orang (10\%) memiliki pengetahuan cukup. Untuk keterampilan praktik dilakukan pengukuran sebelum dan sesudah pelatihan. Berikut adalah hasil keterampilan/praktik terapi akupresur:

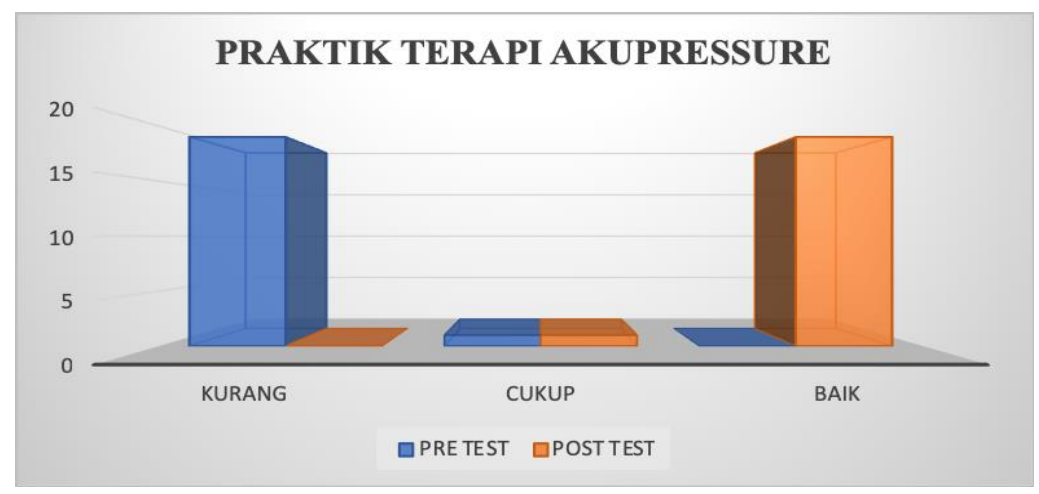

Gambar 2. Hasil Evaluasi Prakti Terapi Akupressure

Dari hasil evaluasi praktik sebelum diberikan pelatihan akupresur sebanyak 19 orang $(95 \%)$ belum mampu mempraktikkan massage akupresur dan sebanyak 1 orang (5\%) sudah pernah melakukan praktik massage akupresur sehingga tergolong kategori cukup. Setelah mendapatkan pelatihan massage akupresur sebanyak 19 orang $(95 \%)$ dapat melakukan praktik dengan kategori baik dan hanya 1 orang $(5 \%)$ yang masih kurang dalam melakukan praktik akupresur.

\section{PEMBAHASAN}

Jumlah bidan yang mengikuti kegiatan ini adalah 20 orang. Bidan-bidan terlihat sangat antusias mengikuti pelatihan ini. Hasil evaluasi pada kegiatan ini menunjukkan terjadi peningkatan pengetahuan dan keterampilan massage akupresur nilai rata-rata 80 . Pelatihan massage akupresur adalah salah satu bentuk pengabdian 
masyarakat yang melibatkan peran serta kelompok bidan sebagai pemberi asuhan utama pada pelayanan kesehatan ibu dan anak. Pada ibu hamil, keluhan nyeri punggung sangat sering dijumpai pada trimester ketiga. Pada kehamilan, hormon progesteron dan hormon relaksasi menyebabkan relaksasi jaringan ikat dan otot-otot. Hal ini terjadi maksimal pada satu minggu terakhir kehamilan. Proses relaksasi ini memberikan kesempatan pada panggul untuk meningkatkan kapasitasnya sebagai persiapan persalinan, tulang pubis melunak menyerupai tulang sendi, sambungan sendi sacrococcigus mengendur membuat tulang koksigis bergeser ke arah belakang sendi panggul yang tidak stabil, hal ini dapat menyebabkan sakit punggung bagian bawah.

Postur tubuh pada ibu hamil secara bertahap mengalami perubahan karena janin membesar dalam abdomen sehingga untuk mengompensasi penambahan berat badan ini, bahu lebih tertarik ke belakang dan tulang lebih melengkung, sendi tulang belakang lebih lentur dan dapat menyebabkan nyeri punggung pada beberapa wanita (Resmi, Hadisaputro, \& Runjati, 2017). Spasme pada otot punggung ini akan terus berlangsung selama kehamilan jika tidak ditangani, karena postur yang menyebabkan spasme ini mengakibatkan nyeri pada punggung bahkan menjalar sampai ke pinggul. Perubahan patologi ditandai dengan adanya nyeri yang bertambah saat melakukan gerakan (nyeri gerak), dan juga adanya nyeri saat dilakukan penekanan (nyeri tekan), kesalahan sikap misalnya cara duduk, cara berdiri, dan berjalan, nyeri berkurang saat digunakan untuk berbaring (Sukeksi, Kostania, \& Suryani, 2018).

Akupressure adalah bentuk fisioterapi dengan memberikan pemijatan dan stimulasi pada titik-itik tertentu pada tubuh (garis aliran energi atau meridian) untuk menurunkan nyeri atau mengubah fungsi (Enggal Hadi Kurniawan, 2016). Ketika titik titk akupresure distimulasi tubuh akan melepaskan ketegangan otot, meningkatkan sirkulasi darah dan meningkatkan kekuatan hidup energi tubuh (qi) untuk membantu penyembuhan (Wong, 2006). Pada beberapa pelayanan antenatalcare belum pernah dilakukan massage akupresur untuk mengurangi keluhan sakit punggung bagan bawah dikarenakan belum semua bidan memiliki kompetensi dalam melakukan massage akupresur, sehingga pada pengabdian masyarakat ini sasaran utama dalam pelatihan massage akupresur adalah kelompok bidan.

\section{KESIMPULAN DAN SARAN}

\subsection{Kesimpulan}

Berdasarkan hasil kegiatan yang telah dipaparkan diatas, kegiatan pengabdian masyarakat ini mendapat respon yang baik dari kelompok bidan. Para bidan sangat antusias untuk mengikuti pelatihan akupresur guna menambah kompetensi dalam memberikan pelayanan komplementer pada ibu hamil dengan keluhan nyeri punggung bagian bawah. Hasil evaluasi pada kegiatan ini menunjukkan terjadi peningkatan pengetahuan dan keterampilan massage akupresur nilai rata-rata 80 . Berdasarkan uraian pada hasil dan pembahasan di atas, maka dapat disimpulkan bahwa pelaksanaan kegiatan massage akupresur pada kelompok bidan berjalan dengan baik. 


\subsection{Saran}

Melakukan pelatihan dengan cakupan wilayah yang lebih luas. Mengoptimalkan sarana dan prasarana yang ada untuk menunjang kegiatan pengabdian masyarakat. Mengembangkan pelatihan komplementer lainnya untuk meningkatkan kualitas kesehatan ibu dan anak.

\section{UCAPAN TERIMA KASIH}

Ucapan terima kasih kepada STIKES Bina Usada Bali.

\section{DAFTAR RUJUKAN}

Aswitami, G. A. P., \& Mastiningsih, P. (2018). Pengaruh Terapi Akupresur terhadap Nyeri Punggung Bawah pada Ibu Hamil TM III di Wilayah Kerja Puskesmas Abian Semal 1. Strada Jurnal Ilmiah Kesehatan, 7(2), 47-51. https://doi.org/10.30994/sjik.v7i2.171

Enggal Hadi Kurniawan. (2016). Terapi Komplementer Alternatif Akupresur Dalam Menurunkan Tingkat Nyeri. Nurseline Journal, 1(2), 246-256.

Global Health Workforce Alliance, Kementerian Kesehatan RI, G. (2011). Rencana Pengembangan Tenaga Kesehatan Tahun 2011 - 2025. (September).

Kemenkes, R. (2018). Tabel Profil Kesehatan Indonesia.

Noviyanti, Astuti I, Hamdah M.N.2016.The Influence of Massage Therapy to Reduce Pain Scale of Inpartu Woman in the Active Phase of the First Stage of Labour (A Case Study in Bandung City).The Southeast Asian Journal of Midwifery, 2,1.

Penelitian dan Pengembangan Kesehatan Kementerian Kesehatan RI. (2018). Laporan Riskesdas 2018. Journal of Chemical Information and Modeling, 53(9), 1689-1699. https://doi.org/10.1017/CBO9781107415324.004

Pravikasari.2014.Perbedaan Senam Hamil dan Teknik Akupresur terhadap Penurunan Nyeri Punggung Bawah pada Ibu Hamil TM III. Semarang:Universitas Diponogoro.

Resmi, D. C., Hadisaputro, S., \& Runjati, R. (2017). Effect of Yoga and Acupressure on Pain and Functional Capability of Lower Back in Pregnant Mothers During the Third Trimester of Pregnancy. Belitung Nursing Journal, 3(6), 722-728. https://doi.org/10.33546/bnj.297

Sneag, D. B., \& Bendo, J. A. (2007). Pregnancy-related low back pain. Orthopedics, 30(10), 839-845. 
Stewart, R. F. (2014). Pelvic Pain During Pregnancy. Retrieved from https://www.parents.com/pregnancy/my-body/aches-pains/pelvic-pain-duringpregnancy/

Suharto. (2001). Exercise untuk nyeri pinggang bawah pada ibu hamil. Jakarta: Cermin Dunia Kedokteran.

Sukeksi, N. T., Kostania, G., \& Suryani, E. (2018). Pengaruh Teknik Akupressure Terhadap Nyeri Punggung pada Ibu Hamil. Jurnal Kebidanan Dan Kesehatan Tradisional, 3(1), 1-56. Retrieved from https://www.google.com/search?safe=strict\&sxsrf=ACYBGNTi6nVLXIsZsNJ u3Ns1PFhHO86xw\%3A1579478648720\&ei=eO4kXpnLK8DB3LUPjcSdoAo $\& q=$ Pengaruh Teknik Akupressure Terhadap Nyeri Punggung Pada Ibu Hamil Di Wilayah Puskesmas Jogonalan I Klaten \& oq = Pengaruh Teknik A

Wang, S.-M., Zinno, P. De, Fermo, L., William, K., Caldwell-Andrews, A. A., Bravemen, F., \& Kain, Z. N. (2005). Complementary and alternative medicine for low-back pain in pregnancy: a cross-sectional survey. Journal of Alternative \& Complementary Medicine, 11(3), 459-464.

Wong, D. L. (2006). Child Nursing Care (Third Edit). St. Louis Missouri: Mosby Elsevier. 